Discussion Paper No. 43

Williams Project on the Economics of Higher Education

Denison Gatehouse

Williams College

Williamstown, MA 01267

\title{
Financing Undergraduate Education: Designing National Policies
}

\author{
Michael S. McPherson \\ Williams College \\ Morton Owen Schapiro \\ University of Southern California
}

DP-43

June 1997

\section{CJune1997 (Michael McPherson, Morton Schapiro)}

Note: This paper is intended for private circulation and should not be quoted or referred to in publication without the permission of the authors. Funding for this paper was provided by the Andrew Mellon Foundation through the Williams Project on the Economics of Higher Education. 
Forthcoming, National Tax Journal, September, 1997

Financing Undergraduate Education:

Designing National Policies

Michael S. McPherson

Macalester College

1600 Grand Avenue

St. Paul, MN 55105

Morton Owen Schapiro

University of Southern California

Administration 304

Los Angeles, CA 90089-4012

\begin{abstract}
In this paper we summarize our recent work analyzing pricing, aid, access and choice in American higher education, and we draw out implications from those findings for national higher education policy. We find that real increases in net tuition have impaired access and choice principally for students from low-income families. The Clinton administration education proposals, rather than addressing the needs of this group, focus on providing tax benefits to middle- and upper-middle income families. We argue that the nation needs a higher education program that provides more assistance to the students for whom the issue of college affordability is the most pressing.
\end{abstract}

We acknowledge the support of the Andrew W. Mellon Foundation and the National Center for Postsecondary Improvement (Agreement No. R309A60001). 
President Clinton's emphasis on higher education policy has elevated the ongoing concern with college affordability to national prominence. In this paper we summarize our recent work analyzing pricing, aid, access and choice in American higher education, and we draw out implications from those findings for national higher education policy.

\section{A Summary of Findings}

Our forthcoming book, The Student Aid Game (McPherson and Schapiro 1997), includes an extensive analysis of evidence on trends in enrollment and financing in American higher education. From that analysis we draw here three points that are important in setting the context for current policy discussions in the United States.

1. Governments, both federal and state, have been providing a decreasing share of American higher education revenues since the mid-1980's. As Table 1 shows, there has been a particularly dramatic reduction in the share of revenues provided by state governments through appropriations to public colleges and universities. States went from providing $43 \%$ of revenues in $1979-80$ to providing $33 \%$ of revenues in $1992-93$. The share has probably fallen further since then. This sharp decline in government contributions has been offset by an increase in the share of revenues providing by students and families through tuition -- a share that has risen from $26 \%$ in $1979-80$ to $35 \%$ in $1992-93$.

The declining share of state contributions has resulted in large part from sustained pressures on state budgets, the product of resistance to paying taxes on one hand and of increasing pressures for states to finance elementary and secondary education, medical care, prisons and other high priority items on the other. Large percentage increases in 
public tuitions. aimed at compensating for contractions in real state government support, have put pressure on families of moderate means, and have certainly added to the political agitation for lower college costs and for more government support to defray college costs.

2. Although more students are attending college than ever before, there are clear signs that higher net costs of college are restricting the college options of lower income students. The overall increase in enrollments is readily explained by the substantial increase in returns to college that has come about as the real earnings of high school graduates have fallen. Yet participation in that enrollment growth has been uneven. Table 2 compares enrollment rates for White, Black and Hispanic high school graduates over time. (Three year moving averages for Blacks and Hispanics are reported to smooth the rapid year-to-year swings in enrollment for these groups produced by small sample sizes.) This table makes clear that enrollment rates have grown more slowly for Blacks and Hispanics than for Whites -- most likely because Blacks and Hispanics have lower incomes on average than Whites and have thus been more vulnerable to rising net costs. Other evidence (Kane 1995) indicates that enrollment rates have grown more slowly for families from the bottom quartile of the income distribution than for families from the top three quartiles.

In addition to this evidence that rising net college costs are discouraging students from lower income families from enrolling in college at all, there is also evidence that students from lower income families who do attend college are finding their choices increasingly constrained by financial pressures. Table 3 reports data on the enrollment destinations of full-time freshmen from various income groups for the years 1980 and 
1994. A striking trend in the table is that smaller shares of students from middle and upper income families have chosen to attend community colleges, while the share of students from lower income families attending these schools has stayed constant or risen. It appears that in many states the only financially viable option for many students from lower-income families is to live at home and attend the local community college. It is no criticism of the education offered at community colleges to note that these lower-income students are being denied options that are available to their more affluent peers.

3. During this period of rising tuition prices and restricted support from state governments, federal student aid has not kept up with increasing costs. Table 4 allows us to compare how families at different income levels financed their educations at different institutional types in 1986-87 and in 1992-93. Federal grants remained approximately constant in real value for low-income students attending private institutions. In light of the considerable real increase in gross tuition, this means that the percentage of tuition covered by federal financial aid for low-income students has decreased considerably over time -- from $22 \%$ in $1986-87$ to only $16 \%$ in $1992-93$. Federal grants for low income students attending public colleges and universities increased slightly in real terms, but not enough to maintain the percentage contribution of these grants to gross tuition: the percentage of tuition covered by federal financial aid for low income students decreased from $68 \%$ in $1986-87$ to $42 \%$ in $1992-93$.

Since the period covered by these data, federal loans for college costs have grown very rapidly. Federal lending grew in real dollars by almost $\$ 9$ billion in the two years between 1992-93 and 1994-95. Probably the most important explanation for this growth is a set of changes in needs analysis methodology introduced in the 1992 reauthorization 
of the Higher Education Act. Students receive interest subsidies on their loans only to the extent that they can be shown to have financial need. Congress, which some years ago decided to write the needs analysis rules themselves, rather than leaving them to student aid experts, made those rules significantly more lenient for middle and upper-middle income students in the 1992 legislation. Most strikingly, a family's home equity was no longer counted as an asset. These changes imply that many families at public institutions who would not have qualified as needy under the old rules can now get subsidized loans. Other factors contributing to the loan run-up probably include the rising costs at public institutions, which also qualify more students for loans, and the introduction of federal direct loans, which have simplified the process of obtaining a loan considerably.

This recent pattern of declining real funding for federal grants coupled with rapid expansion in subsidized loans seems not to reflect a deliberate policy shift, but rather the working out of budgetary pressures. Since grant funds are a form of discretionary spending, their real decline reflects the impact of the general squeeze on the federal budget. Guaranteed loans, by contrast, are an entitlement and so are not affected in the same way in the short run by budget battles. A partial reversal of the trend toward greater reliance on loans was accomplished in 1996, when Congress in an election year voted to increase the maximum Pell grant from $\$ 2300$ to $\$ 2700$.

In sum, then, the background of current policy debates has been set by

- increases in public tuition driven by constrained state government budgets;

- failure of federal student aid programs to keep pace with inflation in college costs; and 
- an increase in federal loans relative to grants. with recent expansions in loans probably benefitting students with relatively high ability to pay.

Although it seems clear that the financial pressures that have resulted from these changes have had their strongest impact on lower income students, these pressures have certainly been felt by a politically vocal and influential group of middle- and upperincome families. Policy proposals introduced by the Clinton administration this year seem focused principally on responding to the cries arising from these middle and upper income families.

\section{Current Federal Policy Initiatives}

The most prominent policy proposals at the time of this writing are the tax breaks that have been advanced by the Clinton administration in its budget for fiscal 1998 . Although these proposals, at least in detail, probably have a short half- life, it is, we think, worth examining them closely, because in fact there is every reason to believe that the incentive effects of such proposals are mightily affected by the details. The President has offered a two-part tax proposal: a non-refundable $100 \%$ credit up to $\$ 1,500$ per student for tuition expenses for students in their first two years of college, and a tax deduction of up to $\$ 10,000$ per taxpayer unit for postsecondary education and training expenses. Taxpayers can elect which tax preference they prefer to use. Both tax preferences recognize only tuition and not room and board as qualifying expenses. To receive the credit in the second year of college, a student must earn a B-average in her first year; no such requirement attaches to the deduction. Joint filers are eligible for the full credit or deduction if their incomes are below $\$ 80,000$; the eligible maximum is reduced to 0 as income rises to $\$ 100,000$. The deduction is "above the line" -- taxpayers 
do not need to itemize to receive it. Importantly, the size of the tax credit available to a student is limited by the number of federal student aid dollars she receives: each dollar of student aid grant reduces eligibility for the tax credit by a dollar. Thus, even if a student had net educational expenses of $\$ 1,500$ after accounting for all sources of aid, her family would not receive any tax credit if $\$ 1,500$ of the aid she received was from the federal government. The net effect of these provisions is to ensure that low-income students at low-cost institutions are unlikely to receive any benefit from the new tax provisions; the largest tax benefits will accrue to families in the $\$ 60,000$ to $\$ 80,000$ whose children attend expensive private colleges (see Gladieux 1997).

Would these new tax provisions tend to cause colleges to raise tuition prices? Effects of the tax credit provision are likely to be limited. Some states still have community college systems in which average tuition is below $\$ 1,500$. To the extent that these schools have populations that qualify for the full $\$ 1,500$ credit, they will certainly have incentives to raise tuition to that level. However, these schools also have important constituencies of part-time and low-income independent students who are unlikely to benefit from the credit, and those constituencies will continue to press for low tuition.

The situation would be considerably different if, as in a Senate Democrat version of the President's bill, students are allowed to receive both a Pell grant and a tax credit. Then students could be eligible for as much as $\$ 4,200$ in aid from Pell and the tax credit combined, and that total exceeds tuition costs at a large number of public institutions. Under these rules, a substantial incentive to capture federal dollars through raising tuition at public institutions would be created. Whether such an incentive would outweigh 
political pressures to keep tuition down is unclear; probably the answer would be different in different states.

The proposed tax deduction is likely to have larger incentive effects than the tax credit (at least in the form proposed by the White House). Most public institutions (though very few private ones) have tuition below $\$ 10,000$. Making tuition tax-deductible would imply that for eligible families, the federal government would pay between $15 \%$ and $28 \%$ of any tuition increase, depending on the family's tax bracket. This would be a significant easing of the burden of higher tuition for families in income ranges of roughly $\$ 40,000$ to $\$ 100,000$-- a quite important constituency for public universities. The political processes that underlie the setting of tuition are certainly complicated ones, but we suspect these incentives could prove significant.

What about the likely impact of these tax preferences on institutions' and state governments' provision of student aid. ${ }^{3}$ We suspect that here the incentive effects are likely to be quite strong (see Breneman 1997). The standard methodology for determining family ability to pay for college should take the added resources provided by these tax breaks into account in determining financial need. There are actually two different ways in which colleges and state student aid agencies might interpret these added resources. On one interpretation, the increase in family after-tax income could simply be seen as added after-tax earning power, similar to any other tax cut a family might receive. In that case the reduction in family need would be a fraction of the increase in after-tax income, that fraction being determined by the marginal taxing rate within the student aid system. A family earning $\$ 60,000$ to $\$ 80,000$ per year that was eligible for state or institutional aid would be expected to contribute about 44 percent of 
the tax break in the form of increased family ability to pay. On a second interpretation. the college tax break might be viewed as an added resource dedicated to college, much like an outside scholarship. In that case, standard methodology would say that all of the added after-tax income should be devoted to educational expenses, and the family's aid from the state or the institution would be reduced dollar for dollar against proceeds of the tax credit or deduction. No doubt schools will vary in the fraction of tax break dollars that they actually capture, but both typical practices and the logic of the need-based student aid system imply that a significant fraction of these dollars would be captured by the schools.

Our conclusion that schools would substitute tax-break dollars for their own student aid dollars is different from the empirical finding reported in some of our earlier work (McPherson and Schapiro 1991) -- that schools increased their own aid spending when Pell spending increased. However, in that case we suggested that this result was explained by the fact that schools were induced by the added Pell availability to recruit more needy students, who then got institution-based aid as well as Pells. Unfortunately, the tax provisions proposed by the Clinton administration are not targeted at the high need students whose college-going behavior is most likely to be influenced by reductions in cost of attendance. We therefore conclude that schools and states are likely to absorb much of the benefit of the tax cuts themselves.

Whether such a transfer from the federal government to state governments and individual private institutions is desirable is a separate question. Although some private colleges and universities would get significant revenues from readjusting their student aid calculations, the bulk of the transfer is likely to be toward public colleges and universities 
and state governments. This is mainly because that is where most of the students are, but also because these institutions will have incentives to raise prices as well as to recalculate aid.

Thus from one point of view, the Clinton proposals could be seen to a significant extent as an intergovernmental transfer -- a federal effort to relieve overstressed state budgets. Indeed it is interesting that the proposed federal revenue loss through these tax cuts of around $\$ 7$ billion per year is the same order of magnitude as the reduction in real support of public higher education by state governments during the 1990s. The President's proposed program would partly relieve families of the added financing burden generated by this reduction in state support and would partly create an environment which encourages further withdrawal of state support.

It is unlikely that those who have advocated this course are aiming at this result. In principle a good case can be made for shifting the principal burden of government finance of higher education from the state to the federal level (a case we have in fact made in McPherson and Schapiro 1991). But at a time when budgetary resources are scarce at all levels of government, it seems desirable to design programs that encourage state and federal governments to be partners in financing higher education, rather than programs that encourage one level of government to replace the efforts of another.

Trying to support access to higher education through the tax system has other drawbacks. Tax benefits, for example, are of limited value in helping folks who are strapped for cash to pay for college, since the relief comes late, when the tax form is submitted, rather than on the spot, as with grants and loans. There is also every reason to expect that some providers of educational services will find ways to help families benefit 
from the tax breaks without providing the services the law intends (see Kane 1997). Although the proposed legislation rules out tax breaks for "leisure-oriented" instruction, identifying and rooting out such instruction is a nightmare to contemplate and is bound to provoke outcry from those whose offerings are not deemed to qualify. Congress should remember the lessons learned in bringing the participation of the proprietary schools under control in the guaranteed student loan program before creating a new program open to similar worries.

Perhaps our greatest reservation about tax subsidies for higher education is this: opening up a channel by which revenue can flow through the tax system to subsidize college expenses is like opening up a new, steeper path that a river can follow to the sea. We suspect that tax credits and buybacks, once in the code, would undergo broadening and deepening to allow favored constituencies to benefit more easily. Dollars headed for the tax side will grow over time and the traditional student aid programs, which are much better vehicles for providing access and choice, will gradually wither.

An obvious alternative to these tax proposals would be to spend equivalent amounts of revenue on expanding the Pell grant program, perhaps in modified form. Senator Paul Wellstone has proposed raising the Pell grant maximum to $\$ 5,000$. A more modest program that would put the 1998-99 Pell grant maximum at roughly its 1979-80 level would call for a $\$ 4,000$ maximum Pell. What would be the incentive effects of such a policy change?

Clearly, such increases would provide low-cost public colleges with incentives to raise tuition. Such incentives are, however, attenuated by two important factors. First, unlike the tax break proposals, which recognize only tuition as an educational cost, Pell 
grant budgets reflect living expenses as well as tuition. Thus, even with a $\$ 4,000$ or $\$ 5,000$ maximum, relatively few schools could make their students eligible for more aid by raising tuition. Moreover, again unlike the tax proposals, Pell grants are designed to decline with increases in family income. Thus even with a larger maximum, relatively fewer students will be able to qualify for larger awards through tuition increases, because the award levels available to most students are well below the maximum because their awards are limited by income.

Incentives for schools to reduce their own student aid awards as Pell awards grow are clearly present, much as with the tax proposals. However, increased Pell awards are much more likely to induce more relatively low-income, high-need students to attend college than would happen with the tax cuts. The presence of more such students would likely induce schools and states to spend more of their own resources on student aid, thus at least partially -- and conceivably more than fully -- offsetting the tendency to substitute higher federal aid for state and institution-based resources.

It is interesting to inquire whether the federal government might be more proactive in forging a partnership with states and institutions. If the federal government is indeed ready to expand its contributions to higher education finance, are there ways to do that while encouraging the other players in the system to maintain or even increase their own efforts?

Attempts by the federal government to mandate the behavior of state governments and individual actors have, for generally good reasons, been met with an increasingly chilly reception. Certainly the ability of the federal government to manage the pricing and aid decisions of states and individual colleges directly is minimal at best. Price 
controls or the like as the cost of greater federal involvement in higher education would be an unworthy bargain and an imprudent line of march for the government.

There may, however, be ways for the federal government to use its considerable financial leverage to produce incentives that will encourage schools and states to direct their policies toward desirable goals.

This is not the place to put forward a fully developed policy proposal for such an intervention. Any such design would need to attend to many complications reflecting variations in the circumstances of different groups of students (e.g., adult students vs. young people who depend on their parents for support) as well as of individual colleges and states. The following policy sketch may, however, usefully illustrate the possibilities.

Suppose that, rather than increasing the Pell grant, as some have advocated, the federal government instead introduced a new grant program "piggy-backed" on top of Pell. These new grants would be means-tested, like Pell, but would also include a new institution-eligibility requirement. For a school's students to be eligible for the new "access" grants, the school would have to demonstrate that it met at least $90 \%$ of the financial need of all full-time, dependent, undergraduate students from families with incomes below $\$ 40,000$ per year. Need would be calculated according to federal formulas, and would be met by a combination of grants, loans, and work, with the amounts met by loan and work bounded by upper limits.

Such a grant program would have some desirable properties. For private institutions, it would ensure that significant institutional aid resources were being allocated to the neediest among its students. Setting the requirement at $90 \%$ of all 
full need (or some other reasonable figure) would guard against making the requirement overly precise, and would also help discourage the possibility that schools would avoid admitting high-need students in order to make the requirement easier to meet.

For public institutions, this program would require one of two things. One option would be for a state to keep its tuition at public institutions low enough for all students to make it feasible for these relatively low income students to have their needs met through available resources. Alternatively, a state that chose to raise tuition (as many have done and likely will continue to do) would need to "recycle" enough of the added tuition dollars to keep college affordable for its low-income families.

Many variations on this basic idea are of course feasible and worthy of discussion. This proposal, for example, is silent on independent and part-time students, simply because full-time dependent students are the easiest group to define and the one for which conventional measures of ability to pay are most adequate. We would argue that proposals on these lines, which recognize explicitly the need for partnership among states, individual schools and the federal government, should be a prominent part of future discussions of federal higher education policy.

\section{Conclusion: Devising National Policies}

Our reading of the evidence is that the group most likely to be placed at risk by the shifting environment of American higher education is the group of low income students who do not have the strong qualifications needed for admission to selective private colleges. And the accompanying purpose of the higher education system that is at risk of being shortchanged is that of providing educational opportunity to qualified students of all backgrounds. As we argued above, for increasing numbers of children 
from low income families, the only educational choice they can meaningfully consider is the local community college. Although this is a good alternative for many students, the choice of whether to attend a local community college or the flagship state university should not be determined by accident of income and location but instead by aspiration and capacity.

Cutbacks in state funding, which have produced rising public tuitions that have not been offset by increasing aid to needy students, play a large role in this constriction of opportunity. But a growing emphasis on merit aid in both public and private institutions and the increasing use of techniques like "need-aware second review" that restrict the flow of institution-based aid to the neediest students have played a part as well. It is not reasonable to expect that individual colleges and universities, struggling with competitive pressures and funding limits, will find the strength to deal with these trends on their own. At the same time the capacity of governments, both state and federal, will be strapped for the foreseeable future by limitations on their ability to raise revenue through taxation. In this environment we would stress the following considerations as critical to state and federal policies. For the states, it is essential in light of funding limitations that they focus their policies clearly on the fundamental purposes of a public university system. In the relative affluence of the 1960s, it was possible for states to conceive and partly execute ambitious "master plans" which found a place for everyone and provided generous subsidies to all who participated. In an era of greater perceived scarcity, the states should be more disciplined in focusing on the essential public purposes of the state colleges and universities. Foremost among these is that of offering a suitable choice of educational opportunities for students of all economic backgrounds. 
This purpose, we would argue, should take precedence over the goal of keeping the brightest students in the home state by offering large merit scholarships to high achievers or the goal of offering a deeply subsidized education to all students, including those from families with a substantial ability to pay.

The federal government, never the most important player in higher education from a financial point of view, has seen its role shrink under budgetary stringencies. More than ever, the federal government must seek to maximize its leverage on the higher education system through using its limited resources intelligently. We would highlight the following points.

First, the federal government must survey the whole higher education scene, and aim to concern itself with those matters that are most likely not to be attended to without its help. Most obviously, there is simply no reason from this point of view for the federal government to get into the merit scholarship game, as President Clinton and various members of Congress have proposed doing. If there is one group of students in this country who can be confident of gaining access to a suitable educational option at an affordable price, it is the group of top performing high school students. The explosion of merit aid through the individual actions of private and public colleges and universities provides significant incentives for many high school students. And if that isn't enough, we must not forget that the system of selective admissions in our nation already provides a powerful incentive for good high school performance. For the federal government to gild that lily is a waste of both energy and resources.

We would lodge this criticism against one feature of the President's tax credit program discussed earlier. Eligibility for this tax credit in a student's second 
college year would depend on his or her earning a B- average in the first year. Although not a terribly high standard, this requirement would cut out a number of, for example, perfectly hardworking $\mathrm{C}+$ students. The B- standard risks encouraging grade inflation, poses problems of administrative cost and complexity and of potential unfairness across institutions with different grading standards, and will further reduce the prospects for disadvantaged students within the program. It is hard to think of a reason for the requirement except to join the bandwagon supporting some kind of merit scholarship principle.

These reservations apply even more strongly to the President's Honors Scholarship proposal. As discussed in the Economic Report of the President (1996): "To focus attention on the value of high school achievement, the Administration has proposed providing $\$ 1,000$ scholarships to the top 5 percent of every high school class, public and private, for use at college. Although the reward is still based on a relative standard, the goal of these awards will be to make the new realities of the labor market more salient, giving students in school a more immediate reason to strive harder.” (p. 206). There is little substantive need for such a program, since highly ranked high school students have excellent collegiate opportunities. Marshall Smith, Under Secretary of Education, (in Lederman 1996) defends the program on the grounds that its cost (estimated to be $\$ 132$ million per year) is tiny relative to overall federal spending on grants and loans, and the program has "symbolic" value.

But we doubt that this really is the type of symbol the federal government ought to provide. Top performing students already have strong incentives to do well. Wouldn't a better symbol be a recommitment to a need-based strategy, reaffirming that every 
qualified student has a legitimate chance at a good college education? Our judgment is that a consistent program of action and of symbols that underscores the continuing importance of educational opportunity for all Americans is a major federal priority.

More generally, as we have said, we believe that it is high-need students who do not have distinguished academic records who are most likely to be neglected in the current higher education climate. This group is not a powerful constituency in most states, and private colleges and universities are increasingly reluctant to offer a large discount to a low income student if they can recruit, say, two more or less comparable lower-need students for the same cost. The best tool available to the federal government for promoting the educational opportunities of this high need group is well-targeted means-tested student aid grants.

Our first lesson, then, concerning the federal role in student finance, is that many of the problems the federal government seems eager to address in higher education -help to middle class families, merit awards for highly able students -- are being addressed in other parts of the system. The problem of providing a range of good educational opportunities for high need students is not being met.

Our second point -- one that is just as important as targeting resources to students who need them most -- is the need for the federal government to recognize in designing its policies that colleges and universities will react to the incentives those policies create, and not passively accept their consequences. We treated this point above, emphasizing in particular some of the worrisome incentive effects that might be created by tax credits and deductions for college. There is every reason to expect that both prices and financial aid practices would respond to such incentives in ways that would lead to the 
colleges themselves capturing a significant fraction of the revenues provided by such deductions. Although there is little evidence that increases in federal aid have contributed to the extraordinary run-up in private college tuitions of recent decades, it is in fact likely that tax deductions or credits for college tuition would do just that. This, in our judgment, would not be a good outcome from a national point of view, and surely it is not the outcome envisioned by those who have advanced these proposals. To make this point is not at all to criticize colleges and universities for reacting in this way (if we are right about how they would react). As actors in a competitive system, it is both predictable and reasonable that they would adjust their policies to a changed fiscal environment.

This second point can also be put in positive terms. While avoiding unintended consequences of the incentives it creates, the federal government should also seek when it can to increase the leverage of its programs by taking into account the incentives its programs create. We believe that the program we sketched, which would provide new supplemental grant funds to students at colleges that met the financial need of their lower-income students -- is a good indication of the kinds of possibilities that should be pursued.

Our third point is related to this second one. While being realistic about the forces guiding both states and institutions, the federal government should also seek to identify when those forces push states and institutions toward outcomes that are socially undesirable and should try, within the limits of its powers, to offset those negative effects. Thus, the combination of "need-aware second review" admission policies and the shift towards merit aid may make a good deal of sense for individual institutions, but help 
explain the worrying trends in college access and choice explored here. The considerable increases in net tuition for low-income students have led to a growing gap between enrollment rates for high-income and low-income students and to an increased concentration of low-income students at the least costly institutions. With merit aid increasing at a faster rate than need-based aid, these trends seem likely to be exacerbated in the future.

So how should the federal government respond? The goal should be to keep the focus on need-based aid from eroding, both in direct federal action and in supporting the need-based dimension of state and institutional policies. This stance does not depend on a claim that the merit components of these policies should be forbidden or actively discouraged by the federal government. Our claim, rather, is that the component of policy that needs to be sustained by the federal government is the need-based one. So the federal government should in the first instance actively fulfill its traditional role of providing aid to needy students. It should at the same time create incentives to push individual institutions to promote that goal as well. We have outlined a new supplemental grant program that illustrates this kind of effort.

Increasing funding for the Pell program is the most obvious way to insure that low-income students will have both access to some type of post-secondary education and some reasonable choice among institutions. Indeed, as we noted earlier, there is some empirical evidence that greater provision of need-based aid by the federal government encourages greater aid expenditures by institutions from their own resources as well. Yet, while between 1980 and 1994 gross tuition at the average public four-year school increased by $86 \%$ in real terms, with an increase at the average private four-year 
colleges of $77 \%$ and an increase at the average public two-year school of $70 \%$, the real value of the maximum Pell grant fell by $27 \%$ over that period. While President Clinton has consistently called for increases in the maximum Pell grant, there is little hope of finding enough resources to restore earlier levels of real funding to the Pell program. Increases in means-tested student aid should receive the highest priority for federal funding in higher education.

We are encouraged by the fact that President Clinton has placed higher education finance at the forefront of the political agenda. There are sound reasons to support the President's commitment to expand federal funding for higher education. But, at the same time, federal dollars to support students' efforts to get a college education are, and will be, very scarce. We must do our utmost to use those precious dollars well. We believe the nation needs a higher education program that has more direct benefits to the students for whom the issue of college affordability is the most pressing. 


\section{Bibliography}

Breneman, David. 1997. "Statement to the Committee on Ways and Means, U.S. House of Representatives." Testimony at the Hearing on Education and Training Tax Provisions of the Administration's Fiscal Year 1998 Budget Proposal. March 5.

Economic Report of the President. 1996. Washington, D.C.: United States Government Printing Office.

Gladieux, Lawrence E. 1997. "Statement to the Committee on Ways and Means, U.S. House of Representatives." Testimony at the Hearing on Education and Training Tax Provisions of the Administration's Fiscal Year 1998 Budget Proposal. March 5.

Kane, Thomas J. 1995. "Rising Public College Tuition and College Entry: How Well Do Public Subsidies Promote Access to College?" National Bureau of Economic Research Working Paper No. 5 164, July.

Kane, Thomas J. 1997. "Beyond Tax Relief: Long-Term Challenges in Financing Higher Education." Testimony before the Committee on Ways and Means, U.S. House of Representatives, at the Hearing on Education and Training Tax Provisions of the Administration's Fiscal Year 1998 Budget Proposal. March 5. Lederman, Douglas. 1996. “Aid for Whom? Clinton Proposes New Merit Scholarships,' But Some Question His Priorities.” The Chronicle of Higher Education, February 2, p. A23 and p. A25. 
McPherson, Michael S. and Morton Owen Schapiro. 1991. Keeping College Affordable. Government and Educational Opportunity. The Brookings Institution, Washington, D.C.

McPherson, Michael S. and Morton Owen Schapiro. 1997. The Student Aid Game. Meeting Need and Rewarding Talent in American Higher Education. Princeton University Press, forthcoming. 
Table 1: Shares of Higher Education Revenue, by Source, Selected Academic Years,

Tuition Paid BY:

\begin{tabular}{lccccc} 
Year & $\begin{array}{c}\text { Gross } \\
\text { Tuition }\end{array}$ & Families & $\begin{array}{c}\text { Insti- } \\
\text { tutions }\end{array}$ & \multicolumn{2}{c}{ Government: } \\
\cline { 3 - 6 } $1939-40$ & 0.37 & 0.35 & 0.02 & 0.00 & 0.00 \\
$1949-50$ & 0.40 & 0.37 & 0.03 & 0.00 & 0.00 \\
$1959-60$ & 0.26 & 0.22 & 0.03 & 0.00 & 0.01 \\
$1965-66$ & 0.26 & 0.21 & 0.04 & 0.00 & 0.01 \\
$1969-70$ & 0.25 & 0.20 & 0.04 & 0.00 & 0.01 \\
$1975-76$ & 0.26 & 0.16 & 0.04 & 0.04 & 0.02 \\
$1979-80$ & 0.26 & 0.14 & 0.04 & 0.06 & 0.02 \\
$1985-86$ & 0.29 & 0.17 & 0.05 & 0.05 & 0.02 \\
$1989-90$ & 0.31 & 0.19 & 0.05 & 0.05 & 0.02 \\
$1991-92$ & 0.34 & 0.22 & 0.05 & 0.05 & 0.02 \\
$1992-93$ & 0.35 & 0.22 & 0.06 & 0.05 & 0.02
\end{tabular}

$\begin{array}{ccc} & \text { Nontuition Revenue: } \\ & & \text { Gifts \& } \\ \text { State \& } & \text { Endowment } \\ \text { Federal Earnings }\end{array}$

$\begin{array}{lll}0.07 & 0.33 & 0.21 \\ 0.12 & 0.32 & 0.12 \\ 0.23 & 0.34 & 0.13 \\ 0.26 & 0.33 & 0.09 \\ 0.22 & 0.38 & 0.08 \\ 0.20 & 0.43 & 0.08 \\ 0.19 & 0.43 & 0.09 \\ 0.16 & 0.41 & 0.10 \\ 0.16 & 0.37 & 0.10 \\ 0.16 & 0.35 & 0.10 \\ 0.16 & 0.33 & 0.10\end{array}$

Notes: 1992-93 data are preliminary. Both veteran's educational benefits and social security benefits paid to qualified college students are excluded from federal tuition payments.

Source: See McPherson and Schapiro 1991A, p. 23, plus, for data after 1986, Table 318 (p. 330) of the Diaest of Education Statistics 1995, National Center for Education Statistics (October 1995) and Table 1 (p. 4) of Trends in Student Aid: 1985 to 1995, The College Board (September 1995). 
Table 2: College Enrollment Rates of High School Graduates Whites Blacks 3-yr. ave. Hispanics 3-yr. ave.

\begin{tabular}{|c|c|c|c|c|c|}
\hline 1960 & 45.8 & -- & - & -- & - \\
\hline 1961 & 49.5 & -- & - & -- & - \\
\hline 1962 & 50.6 & -- & - & -- & - \\
\hline 1963 & 45.6 & -- & -- & -- & - \\
\hline 1964 & 49.2 & -- & $\cdots$ & -- & - \\
\hline 1965 & 51.7 & -- & -- & $-^{-}$ & - \\
\hline 1966 & 51.7 & -- & -- & - & - \\
\hline 1967 & 53.0 & -- & -- & - & - \\
\hline 1968 & 56.6 & -- & - & - & - \\
\hline 1969 & 55.2 & -- & - & - & - \\
\hline 1970 & 52.0 & -- & - & $-^{-}$ & - \\
\hline 1971 & 54.0 & -- & - & - & - \\
\hline 1972 & 49.4 & -- & - & - & - \\
\hline 1973 & 48.1 & - & - & - & - \\
\hline 1974 & 47.1 & - & - & - & - \\
\hline 1975 & 51.2 & -- & - & - & - \\
\hline 1976 & 48.9 & 41.9 & - & 52.6 & - \\
\hline 1977 & 50.7 & 49.6 & 45.7 & 51.3 & 48.9 \\
\hline 1978 & 50.1 & 45.7 & 46.9 & 42.9 & 46.3 \\
\hline 1979 & 49.6 & 45.4 & 44.3 & 44.8 & 46.8 \\
\hline 1980 & 49.9 & 41.8 & 43.4 & 52.7 & 49.9 \\
\hline 1981 & 54.6 & 42.9 & 40.4 & 52.1 & 49.3 \\
\hline 1982 & 52.0 & 36.5 & 39.3 & 43.1 & 49.8 \\
\hline 1983 & 55.0 & 38.5 & 38.4 & 54.3 & 47.3 \\
\hline 1984 & 57.9 & 40.2 & 40.3 & 44.3 & 49.9 \\
\hline 1985 & 59.4 & 42.3 & 39.7 & 51.1 & 46.6 \\
\hline 1986 & 56.0 & 36.5 & 43.6 & 44.4 & 43.0 \\
\hline 1987 & 56.6 & 51.9 & 44.5 & 33.5 & 45.0 \\
\hline 1988 & 60.7 & 45.0 & 49.9 & 57.0 & 48.6 \\
\hline 1989 & 60.4 & 52.8 & 48.0 & 55.4 & 53.2 \\
\hline 1990 & 61.5 & 46.3 & 48.2 & 47.3 & 53.3 \\
\hline 1991 & 64.6 & 45.6 & 46.6 & 57.1 & 53.1 \\
\hline 1992 & 63.4 & 47.9 & 49.7 & 54.8 & 58.1 \\
\hline 1993 & 62.8 & 55.6 & 51.5 & 62.5 & 55.4 \\
\hline 1994 & 63.6 & 50.9 & & 48.9 & \\
\hline
\end{tabular}

Note: enrollment rates reflect enrollment in college as of October of each year for individuals age 16 to 24 who graduated from high school (including GED recipients) during the preceding 12 months.

Source: based on information presented in Table 177 (p. 187) of the Digest of Education Statistics 1095, National Center for Education Statistics (October 1995). 
Table 3: Distribution of Freshman Enrollment By Income Background Across Institutional Types

1994

Private

4-Year Colleges

2-Year Colleges

All Private

Public

University

4-Year Colleges

2-Year Colleges

All Public

1980

Private

University

4-Year Colleges

2-Year colleges

All Private

Public

University 4-Year Colleges

2-Year colleges

All Public

$\begin{array}{cc}\text { Lower } & \text { Lower } \\ \text { Middle } & \$ 20-\$ 30\end{array}$

\section{$2.6 \%$}

$12.8 \%$

$3.1 \%$

$18.5 \%$

$10.9 \%$

$23.2 \%$

$47.3 \circ$

$81.4 \%$

$100.0 \%$

$<\$ 10$

$2.2 \%$

$13.4 \%$

$5.6 \%$

$21.2 \%$

$10.1 \%$

$22.8 \%$

$45.9 \%$

$78.8 \%$

$100.0 \%$

$$
\begin{array}{r}
3.3 \% \\
15.3 \%
\end{array}
$$$$
2.9 \%
$$

$21.5 \%$

$14.5 \%$

$24.6 \%$

$39.4 \%$

$78.5 \%$

$100.0 \%$

$\$ 10-\$ 15$

$15.1 \%$
$5.1 \%$

$23.1 \%$

$13.2 \%$

$21.3 \%$

$42.4 \%$

$76.9 \%$

$100.0 \%$

\section{Middle}

$\$ 30-\$ 60$

Upper

Middle

$\$ 60-\$ 100$

$3.9 \%$
$16.6 \%$
$2.5 \%$

$6.6 \%$
$18.4 \%$
$2.2 \%$

$23.0 \%$

$27.2 \%$

$18.1 \%$

$25.2 \%$

$33.7 \%$

$77.0 \%$

$100.0 \%$

$\$ 15-\$ 30$

$3.9 \%$

$15.8 \%$
$3.7 \%$

$23.4 \%$

$17.4 \%$

$20.4 \%$

$38.9 \%$

$76.7 \%$

$100.0 \%$
$24.9 \%$

$25.9 \%$

$22.1 \%$

$72.9 \%$

$100.0 \%$

$\$ 30-\$ 50$

$$
\begin{array}{r}
6.8 \% \\
17.7 \% \\
3.3 \%
\end{array}
$$

$27.8 \%$

\section{$24.6 \%$}

$20.1 \%$

$27.6 \%$

$72.3 \%$

$100.0 \%$ $\begin{array}{cc}\text { Upper } & \text { Richest } \\ \text { O0- } \$ 200 & >\$ 200\end{array}$

$13.2 \%$
$22.2 \%$
$2.8 \%$

$38.2 \%$

$27.8 \%$

$20.1 \%$

$13.9 \%$

$61.8 \%$

$100.0 \%$

$\$ 50-\$ 100$

$12.8 \%$

$25.2 \%$

$2.6 \%$

$40.6 \%$

$26.6 \%$

$15.6 \%$

$17.3 \%$

$59.5 \%$

$100.0 \%$

4.0

$100.0 \%$
All Groups

$5.7 \%$

$17.1 \%$

$2.7 \%$

$25.5 \%$

$19.1 \%$

$24.1 \%$

$31.3 \%$

$74.5 \%$

$100.0 \%$

All Groups

$5.2 \%$

$16.8 \%$

$4.0 \%$

$26.0 \%$

$18.1 \%$

$20.2 \%$

$35.8 \%$

$74.1 \%$

$100.0 \%$

Source: calculated from results from The American Freshman Survey. 
Table 4: Financing Undergraduate Tuition, 1986-87 and 1992-93. In 1992-93 Dollars

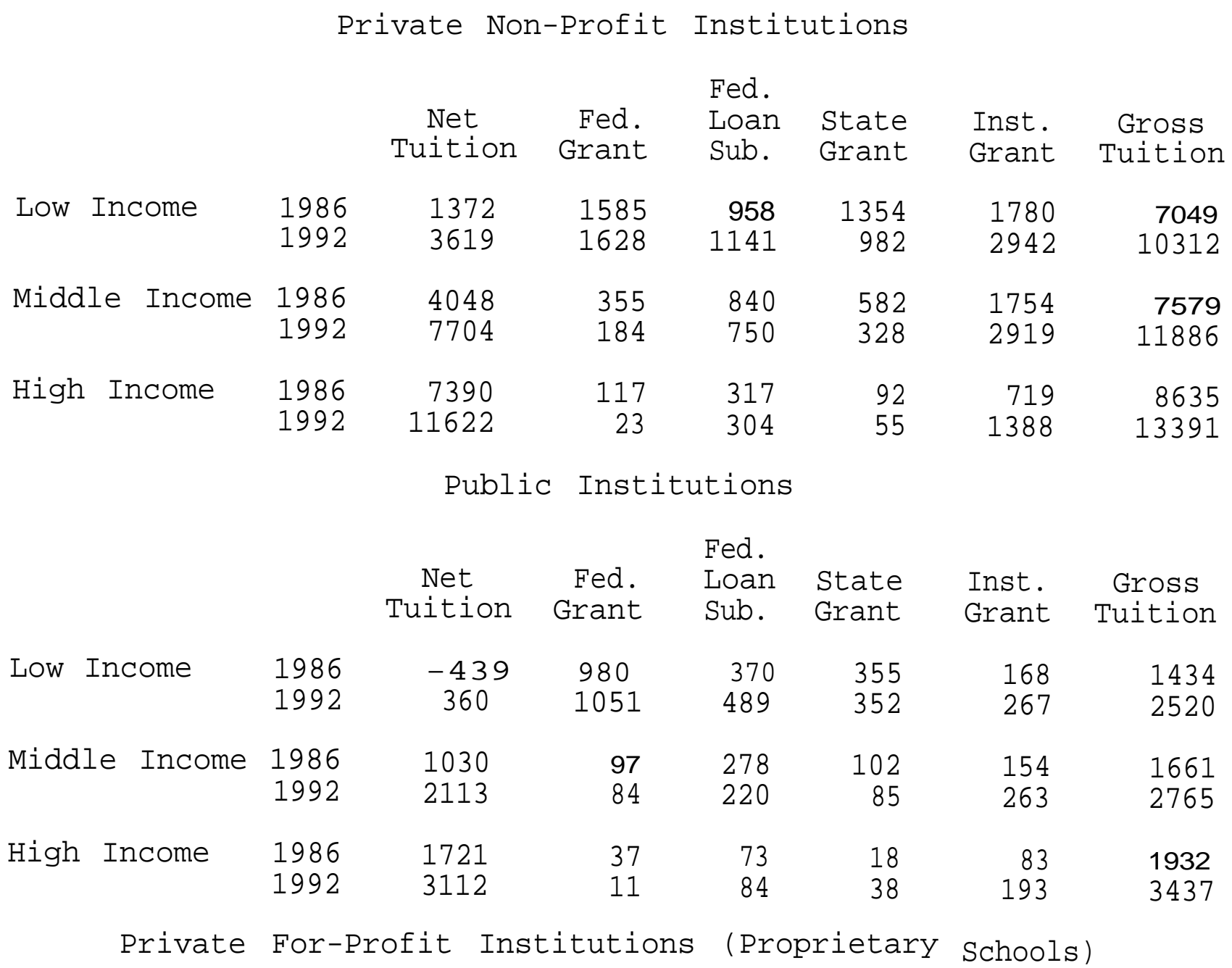

$\begin{array}{lrrrrrrr} & & \begin{array}{c}\text { Net } \\ \text { Tuition }\end{array} & \begin{array}{c}\text { Fed. } \\ \text { Grant }\end{array} & \begin{array}{l}\text { Fed. } \\ \text { Loan } \\ \text { Sub. }\end{array} & \begin{array}{r}\text { State } \\ \text { Grant }\end{array} & \begin{array}{r}\text { Inst. } \\ \text { Grant }\end{array} & \begin{array}{c}\text { Gross } \\ \text { Tuition }\end{array} \\ \text { Low Income } & 1986 & 1124 & 1546 & 1233 & 266 & 70 & 4238 \\ & 1992 & 4155 & 1254 & 1102 & 122 & 69 & 6702 \\ \text { Middle Income } & 1986 & 3281 & 180 & 1245 & 207 & 105 & 5018 \\ & 1992 & 5842 & 94 & 784 & 69 & 110 & 6898 \\ \text { High Income } & 1986 & 4630 & 33 & 349 & 27 & 62 & 5102 \\ & 1992 & 6852 & 7 & 188 & 0 & 25 & 7071\end{array}$

Note: Numbers are averages across all full-time, dependent students attending a particular institutional type.

Source: Calculated from 1986-87 and 1992-93 NPSAS data bases. 